\title{
STABLE CARBON ISOTOPE MEASUREMENTS ON HAIR FROM WILD ANIMALS FROM ALTIPLANIC ENVIRONMENTS OF JUJUY, ARGENTINA
}

\author{
Héctor O Panarello \\ Instituto de Geocronología y Geología Isotópica, CONICET, Pabellón INGEIS, Ciudad Universitaria, (1428) Buenos Aires, \\ Argentina. Email: hector@ingeis.uba.ar. \\ Jorge Fernández $\mathrm{C}^{1}$ \\ CONICET \& Instituto Nacional de Antropología y Pensamiento Latinoamericano, 3 de Febrero 1370, (1426) Buenos Aires, \\ Argentina.
}

\begin{abstract}
The use of stable carbon isotopes as dietary tracers is an application that is widening its scope within the fields of ecology and paleoecology. Although hair is potentially one of the most favorable animal tissues for isotopic measurement for dietary studies, this tissue is rarely included in research works. This may be due to the fact that many aspects related to hair tissue are not fully understood, especially in the case of wild animals whose diets consist of plants with contrasting ${ }^{13} \mathrm{C} /{ }^{12} \mathrm{C}$ ratios, their abundance depending on seasonality. The present isotopic study of hair from animals inhabiting the Andes in northwestern Argentina, at heights ranging from 3500 to about $5000 \mathrm{~m}$ above sea level (asl) shows that 1 ) $\delta^{13} \mathrm{C}$ values measured on hair from herbivores with a mixed and isotopically contrasting diet, and from their carnivorous predators, differ in their respective trophic levels, 2) in primary consumers, different types of hair from the same individual have different $\delta^{13} \mathrm{C}$ values, whereas hair values are homogeneous in carnivores, and 3) some types of hair from rodents, such as whiskers, show $\delta^{13} \mathrm{C}$ values similar to those of less metabolically active tissues such as bone collagen.
\end{abstract}

\section{INTRODUCTION}

Although the isotopic signatures that can be correlated with mammals' diets can be measured on any type of material from the organism, several circumstances have contributed to make bone the material preferred by researchers. The physical and chemical pretreatment for obtaining bone collagen or bone gelatin, on which measurements are generally made, involves strong acid and alkaline reagents, and temperatures ranging from $-70^{\circ}$ to $90^{\circ} \mathrm{C}$. The features involved in this process may create doubts about the validity of some of the results obtained. In modern environments, and also under exceptional conditions in prehistoric environments, in order to carry out isotopic measurements, any other animal material is preferable to bone. Moreover, $\delta^{13} \mathrm{C}$ values measured on bone collagen average the isotopic values of the food eaten and, thus, mask the dietary variations that could have taken place during the life of human or animal individuals. Therefore, seasonal variations in the carbon isotopic composition of the diet cannot be established using collagen due to its slow turnover rate. Information about variations in diet can be very important when studying food chains that involve isotopically contrasting plants, such as $\mathrm{C}_{3}$ and $\mathrm{C}_{4}$. Other tissues with faster turnover rates can provide information on the food eaten during short periods of time prior to death (Schwarcz and Schoeninger 1991).

The use of hair for isotopic measurements has several advantages. Individuals under study do not have to be sacrificed and, thus, can be re-examined over long periods of time under either constant or varying environmental and dietary conditions. Sampling is quick and, after surveying the samples under a microscope to verify their state of conservation and the absence of parasites, eggs, or dejections, pretreatment consists only of washing them with extremely volatile solvents. Also, the turnover rate of all the dietary isotopes is fast. The isotopic enrichment factor relative to diet, which is slightly over 5\% in collagen, decreases to 1\%o in hair (Minson et al. 1975; DeNiro and Epstein 1978; Jones et al. 1981; Tieszen et al. 1983). In the case of natural feeding, fractionation has been greater, around 1.3 and 3.4 (Nakamura et al. 1982; Schoeller et al. 1986; Katzenberg and Krouse 1989; White 1993; Fernández C et al. 1999).

${ }^{1}$ Deceased 24 December 2001. 
Despite the important information provided by hair analysis, the use of this tissue is limited. It has been used mainly for comparison almost exclusively during the initial stage of dietary research using isotopic tracers. This research was carried out with laboratory animals and under controlled and isotopically constant diets (Minson et al. 1975; DeNiro and Epstein 1978; Jones et al. 1981; Tieszen et al 1983). Therefore, little is known about what happens in natural settings where animals fill their energy needs freely and completely. We aim here to contribute to the knowledge of these wild environments and to provide a better understanding of the way in which stable carbon isotopes are transferred following the energy flux from plants to animals, both herbivores and carnivores, belonging to different trophic levels, living in the remote and unpolluted environment of the Andes in northwestern Argentina.

\section{NATURE AND PROVENANCE OF SAMPLES}

The Puna of Jujuy is a high, arid plain located between the western and eastern Andes (Figure 1). It shows remarkable ecologic variability, possibly due to its relief, which includes heights ranging from 3500 to over $6000 \mathrm{~m}$ asl. The increases in height occur within short horizontal distances, influencing plant and animal distribution. The distribution resembles a complicated biological chessboard, changing within short distances due to factors determined by altitude.

A remarkable aspect of the animal community of this region is the strong predominance of herbivores in spite of the scarcity and discontinuity of vegetal cover. Out of this variety of plants and animals, the small sample presented in this work corresponds to 3 well-defined ecosystems, for both its altitude and its biological content. These ecosystems constitute strips of land with an $\mathrm{E}-\mathrm{W}$ alignment and with a latitude almost coinciding with the Tropic of Capricorn.

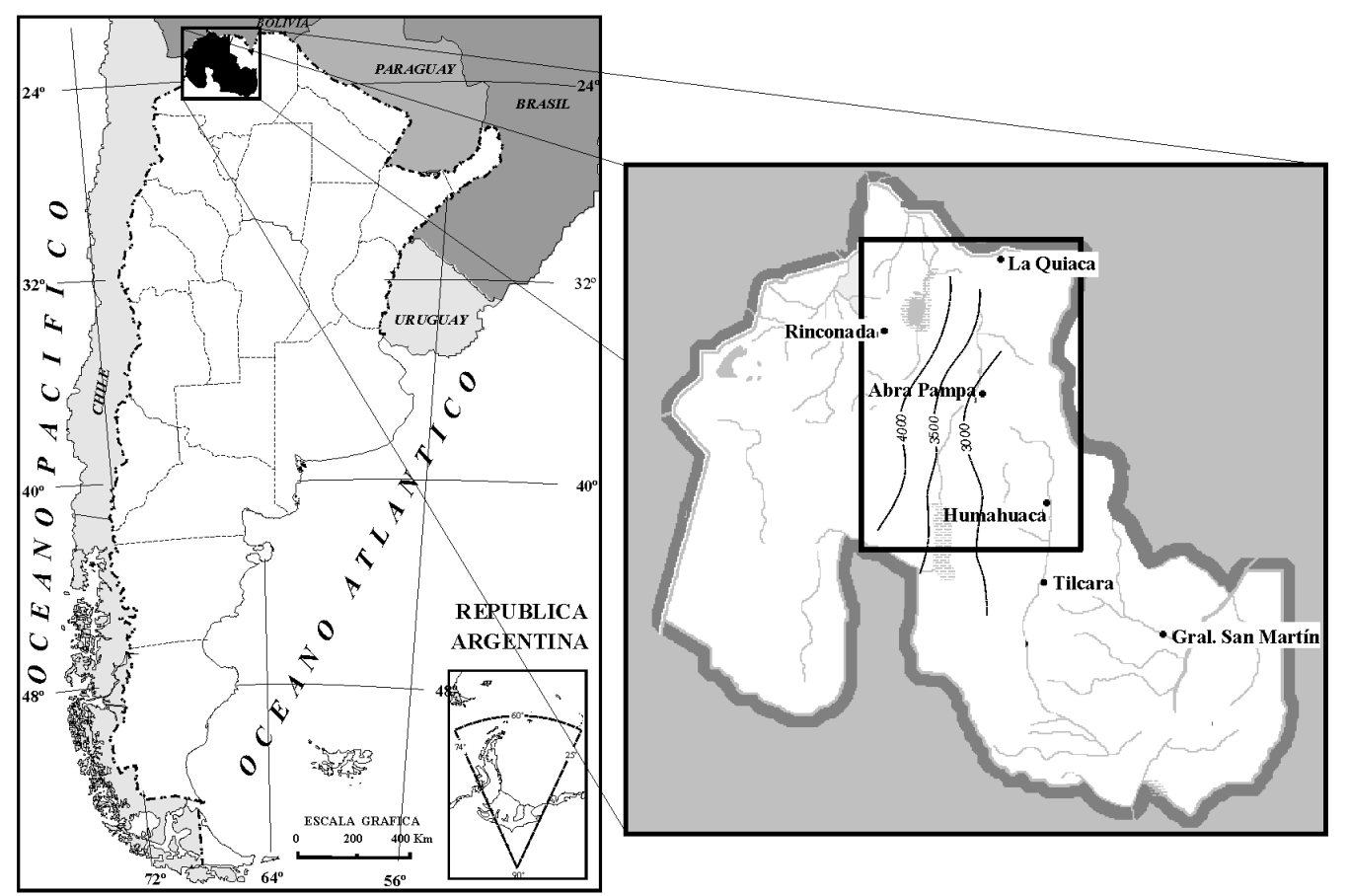

Figure 1 Geographic location of the study area 
The first ecosystem occurs on the sides of isolated mountains, at heights varying from 4000 to about $5000 \mathrm{~m}$ asl, where annual rain, concentrated in the summer months, is $300 \mathrm{~mm}$. In spite of the latitude, height makes night temperatures reach glacial values. The vegetation of this semi-arid region consists of a succession of scrub and grass steppes which follow the $\mathrm{C}_{3}$ photosynthetic pathway, with the exception of Muhlenbergia. The large herbivores that inhabit this ecosystem are 2 wild camelids, the guanaco (Lama guanicoe), and the vicuña (Vicugna vicugna). Regarding their feeding habits, both camelids are indistinctly grazers and browsers. The puma (Puma concolor) is their main predator.

The second environment is characterized by the intense diaphaneity and great luminosity of its sky and corresponds to the mountainsides with heights ranging from 3600 to $4000 \mathrm{~m}$. There is a marked difference between day and night temperatures. The land is covered by rock detritus and dunes, on which shrubs and mats grow forming discontinuous groups. Most of the monocotyledon plants follow the $\mathrm{C}_{3}$ photosynthetic pathway, but there are also localized grasslands of Pennisetum chilensis and Sporobolus rigens, both $\mathrm{C}_{4}$ species. This is the habitat of a digging rodent, Ctenomys sp., a type of mole that lives in underground burrows and feeds on roots.

The third ecosystem is found at lower heights $(3500 \mathrm{~m})$, in the Altiplano itself. It is hyper-arid, the sky is clear and luminous, and annual rain values barely reach $100 \mathrm{~mm}$. Nights are extremely cold. The relief consists of rocky outcrops where some shrubs and cacti grow in cushion-like shapes. Colonies of medium-size herbivorous rats, the chozchori (Octodontomys gliroides), live in this rocky habitat. Because there is little information about these rats in specialized literature, we will discuss some of their biological characteristics in more detail below.

Apparently due to the dangers posed by its feathered (owl, eagle, falcon) and terrestrial predators (fox, Dusicyon $s p$.; wildcat or oscollo, Felis $s p$.), the octodontic rat chozchori cannot have direct access to water. Its habitat being limited to cracks and holes in the rocks, this species seems to have developed strategies to cope with this lack of water availability by 1) developing the ability to regulate water consumption by means of urine concentration, 2) building shelters with available materials consolidated with indurated urine, and 3) feeding on vegetal species that accumulate water excess, such as cacti. In some aspects, the behavior of the chozchori rat is similar to that of the North American packrat (Neotoma), whose middens occasionally reach ${ }^{14} \mathrm{C}$ ages over $20,000 \mathrm{BP}$. They represent a primary source for the reconstruction of the climatic and biological past in arid regions. Taking into account the paleoenvironmental and paleoclimatic information that could be potentially preserved in the indurated middens of the Octodontomys, this species has been chosen for the present study.

Each of the animal species inhabiting the 3 environments considered can, to a certain extent, modify the composition of its diet mainly due to seasonal availability of food rather than by their own free will. Some of the vegetal species disappear completely during the toughest seasons and herbivores are forced to replace them by other species. This change in diet does not modify the isotopic values of the tissue of the herbivore, as long as it does not imply the consumption of plants that follow different photosynthetic pathways.

Direct field observation shows that the guanaco and the vicuña seasonally modify the vegetal composition of their diet, browsing more during winter (Table 1A-B). But this change does not imply an intake of plants with a different photosynthetic pathway. The same applies to the rodent (Ctenomys) living in the environment at intermediate heights. 
On the other hand, field observations concerning the dietary habits of the chozchori (Octodontomys) show important seasonal changes. During winter, there is a marked dependence on cacti of the genus Maihueniopsis that is a CAM-type plant (crassulacean acid metabolism) photosynthesizing as $\mathrm{C}_{4}$ and during summer, there is a supplementary intake of $\mathrm{C}_{3}$ fresh grasses (Table 1C).

Table $1 \delta^{13} \mathrm{C}$ values of plants from environments at different altitudes in the Argentine Altiplano

\begin{tabular}{llll}
\hline \multicolumn{1}{l}{ Species } & Common name & Altitude $(\mathrm{m})$ & $\delta^{13} \mathrm{C} \%$ (PDB) \\
\hline A) Plants eaten by camelids (guanaco and vicuña) & & \\
Ephedra breana & Paraguay & $4000-5000$ & -21.6 \\
Trifolium amabile & Paja blanda & $4000-5000$ & -25.5 \\
Poa juyensis & Suico & $4000-5000$ & -26.4 \\
Tagetes multiflora & Cebadilla & $4000-5000$ & -27.3 \\
Poa anua & Pasto blando & $4000-5000$ & -25.9 \\
Poa lilloi & Cienego & $4000-5000$ & -250 \\
Cotula mexicana & Pasto cebadilla & $4000-5000$ & -27.8 \\
Bromus catharticus & - & $4000-5000$ & -285 \\
Poa jujuyensis & - & $4000-5000$ & -26.7 \\
Festuca orthophylla & - & $4000-5000$ & -27.5 \\
B) Plants eaten by tojos (Ctenomys sp.) & & \\
Nassauvia axillaris & - & $3600-4000$ & -26.8 \\
Ephedra breana & Pingo-pingo & $3600-4000$ & -21.6 \\
Nassauvia axillaris & - & $3600-4000$ & -26.8 \\
C) Plants eaten by chozchoris (Octodontomys gliroides) & & \\
Maihueniopsis glomerata & Espina binacilla & 3500 & -15.3 \\
Maihueniopsis boliviana & Quepo & 3500 & -15.5 \\
Maihueniopsis sp. & Pushcaia & 3500 & -13.1 \\
Tarassa sp. & Malva & 3500 & -23.7 \\
Graphalium lacteum & Oreja-oreja & 3500 & -26.1 \\
Senecio graveolens & Vira-vira & 3500 & -31.6 \\
\hline
\end{tabular}

\section{METHODS AND MATERIALS}

With the exception of chozchori (Octodontomys) specimens 3 and 4, none of the animals considered in this study has been intentionally sacrificed for the experiments. Therefore, in some cases we have not been able to get and analyze perishable parts of the animals.

The bodies of the large Andean herbivores (guanaco, Lama guanicoe; vicuña, Vicugna vicugna) inhabiting the highest ecosystem $(3500-5000 \mathrm{~m})$ are covered by an animal "fiber" similar to wool and possibly sharing the same physical and chemical properties. Therefore, sampling was limited to the short hair present in the inner side of the thigh.

Since the hair of the rodent from the second ecosystem (tojo, Ctenomys sp.) is very short in the ventral part and on the tail, samples were taken only from the dorsal part.

In the case of the chozchori (Octodontomys sp.), we found 3 types of hair that can be differentiated both for its location as for its functionality and possibly also for its physical and chemical characteristics: 1) whiskers, extremely long, as in all rodents, 2) hair on the tip of the tail, which forms a kind 
of tuft or brush, and 3) snowy-white hair that covers the animal's belly. To establish the grade of homogeneity of the carbon isotopic distribution in the chozchori (Octodontomys gliroides), we collected samples of these 3 types of hair from each individual analyzed. The same procedure was followed in the case of the identified chozchori carnivorous predators from the same locality and ecosystem: the wildcat or oscollo (Felis sp.) and the fox (Dusicyon sp.).

Hair samples were examined under a microscope and magnifying glass to remove any possible contaminants (dirt, parasites, or eggs) and later washed with sulfuric ether and dried in a stove.

Parts of diaphysary bones were obtained from the animals' skeletons. The remaining tissues were removed with a scalpel and the bone fraction was defatted in a Soxhlet with sulfuric ether. The decalcification organic residuum was extracted following the method of Sealy (Sealy and van der Merwe 1986), with modifications. The product resulting from the bone decalcification treatment described is informally referred to as collagen in this paper.

In order to calibrate the ${ }^{13} \mathrm{C} /{ }^{12} \mathrm{C}$ ratios both in the bone decalcification organic residuum and in mammals' hair, samples of plants conforming their diet were taken along a height and humidity gradient from the low lands at $3500 \mathrm{~m}$ inhabited by the chozchori (Octodontomys), up to the snow line, at almost $5000 \mathrm{~m}$, the height reached by the camelids (guanaco and vicuña) in the region. We were not able to compare the feeding habits observed with what was actually eaten by the animals. Materials such as stomach contents and dejections, which would make this control possible (Jones et al. 1979), cannot always be easily identified and collected in the case of small animals living in burrows in rough areas. Plants were identified by species and, on the basis of leaf anatomy and $\delta^{13} \mathrm{C}$ values, were grouped according to their photosynthetic pathway in $\mathrm{C}_{3}, \mathrm{C}_{4}$, and CAM (Table $1, \mathrm{~A}-\mathrm{C}$ ).

$\delta^{13} \mathrm{C}$ analyses were done at the Instituto de Geocronología y Geología Isotópica (INGEIS) in Buenos Aires, Argentina following the technique described by Panarello (1987). About $8 \mathrm{mg}$ of each sample of hair, bone decalcification residuum, and vegetal matter was mixed with $100 \mathrm{mg} \mathrm{V}_{2} \mathrm{O}_{5}$ in a Pyrex vial and flame sealed under a vacuum of about $10^{-2}$ Pascal. The sample was combusted for $8 \mathrm{hr}$ at $550{ }^{\circ} \mathrm{C}$ in an electric furnace. $\mathrm{CO}_{2}$ gas was then purified by cryogenically removing water and non-condensable gases, trapped with liquid nitrogen, and transferred to a Micromass 602-D McKinney type mass spectrometer. Results are expressed as $\delta$, defined as follows:
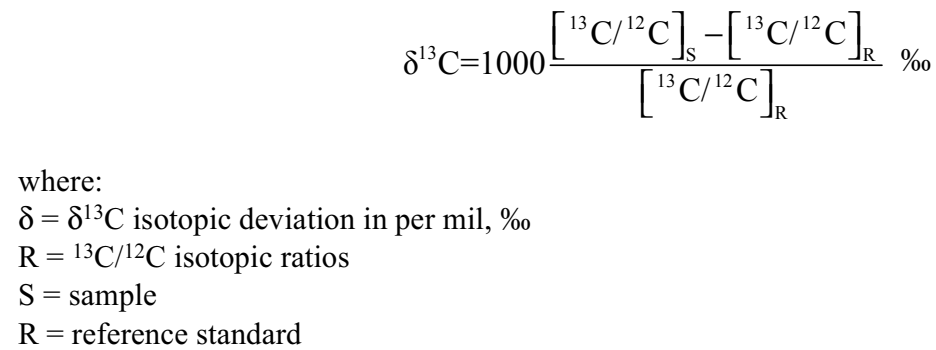

The standard is V-PDB as defined by Gonfiantini (1984) on the basis of PDB (Craig 1957). The standard measurement error is $\pm 0.1 \%$. Table 1 shows the stable carbon isotopic values from the plants that compose the diet of the chozchori (Octodontomys gliroides) and of the other groups of animals we have selected for comparison. Table 2 shows the $\delta^{13} \mathrm{C}$ values measured on hair and collagen of camelids and of Ctenomys sp., and on the different types of hair and on the bone decalcification residuum of the chozchori (Octodontomys gliroides) and of its predators: 2 carnivores inhabiting the same locality, the wildcat or oscollo (Felis sp.) and the fox (Dusicyon sp.). 
Table $2 \delta^{13} \mathrm{C}$ values of different types of hair and of bone collagen from Octodontomys gliroides, from its predators (Felis sp. and Dusicyon sp.), and from other animals from the Andean Altiplano

\begin{tabular}{llccccc}
\hline & & \multirow{2}{*}{ Altitude } & \multicolumn{3}{c}{ Hair $\left(\delta^{13} \mathrm{C} \%\right.$ PDB $)$} & \multirow{2}{*}{ Collagen } \\
\cline { 5 - 6 } Species & Common name & $(\mathrm{m})$ & Whiskers & Tail & Belly & $\left(\delta^{13} \mathrm{C} \%\right)$ \\
\hline Octodontomys gliroides & Chozchori & 3500 & -12.5 & -15.8 & -16.2 & -12.3 \\
Octodontomys gliroides & Chozchori & 3500 & -13.0 & -15.2 & -17.7 & -12.0 \\
Octodontomys gliroides & Chozchori & 3500 & -12.4 & -16.7 & -14.2 & -12.2 \\
Octodontomys gliroides & Chozchori & 3500 & -13.2 & -12.4 & -13.8 & -10.9 \\
Felis sp. & Wild cat & 3500 & -15.5 & -15.2 & -15.9 & -13.6 \\
Dusicyon sp & Fox & 3500 & - & - & - & -13.8 \\
Ctenomys sp. & Tunduco & 3700 & - & - & -19.8 & -13.8 \\
Lama guanicoe & Guanaco & 4500 & - & - & -21.7 & -20.1 \\
Vicugna vicugna & Vicuña & 4500 & - & - & -22.1 & -20.0 \\
Puma concolor & Puma & 4000 & - & - & -17.0 & -16.1 \\
Puma concolor & Puma & 4300 & & & -19.1 & -18.0 \\
\hline
\end{tabular}

\section{RESULTS}

$\delta^{13} \mathrm{C}$ values of plants from the mountain slopes between 4000 and $5000 \mathrm{~m}$ (Table 1A), grazed or browsed by the camelids (guanaco and vicuña), average $-26.2 \%$. All these plants correspond to $\mathrm{C}_{3}$ species. Assuming that $\delta^{13} \mathrm{C}$ values of collagen from animals of the size of those considered in this study show an enrichment of 5.1-5.3\% relative to diet (van der Merwe 1982, 1986), we find that $\delta^{13} \mathrm{C}$ values of collagen from camelids (guanaco $=-20.1 \%$ and vicuña $=-20.0 \%$ ) agree with the expected values. $\delta^{13} \mathrm{C}$ values of hair are more positive than those of diet by up to $1 \%$ (DeNiro and Epstein 1978), but this is not seen in the case of camelids. On the contrary, $\delta^{13} \mathrm{C}$ values of hair from camelids are similar to those measured on collagen, possibly because the "hair" that covers these animals (pelage) has characteristics that are more similar to wool than hair, with its resulting chemical differentiation.

The plants eaten by the tojo (Ctenomys $s p$.) in the intermediate environment of the Altiplano, at heights of 3700 to $4000 \mathrm{~m}$ (Table 1B), include a $\mathrm{C}_{4}$ gramineae (Sporobolus rigens); therefore, the average $\delta^{13} \mathrm{C}$ value of the diet is estimated at $-20.1 \%$. This value is reasonably reflected in the $\delta^{13} \mathrm{C}$ values of the tojo collagen $(-13.8 \%)$ and hair $(-19.8 \%)$.

The cacti eaten by the chozchori (Octodontomys), in the Altiplano itself, are CAM species that photosynthesize following the $\mathrm{C}_{4}$ pathway. They show a mean $\delta^{13} \mathrm{C}$ value equal to $-14.6 \%$. The $\delta^{13} \mathrm{C}$ value of the $\mathrm{C}_{3}$ species on which the chozchori complementary feeds averages $-26 \%$. The difference between both ends of the combined diet is $-11.5 \%$. Taking an enrichment of $1 \%$, these dietary values will be fixed in the hair of animals feeding on either $100 \% \mathrm{C}_{3}$ or $100 \%$ CAM plants with values equal to -25.0 and $-13.5 \%$, respectively. If we compare this last value with the isotopic values measured on ventral hair of chozchori specimens 3 and 4, captured at the beginning of winter, we can see that their diet was exclusively formed by CAM plants. On the other hand, specimens 1 and 2 reflect the mixed summer diet, with up to $20-35 \%$ of $\mathrm{C}_{3}$ plants (Table 2 ). This seasonality in diet cannot be detected by the isotopic composition of collagen $(-12.2$ and $-10.9 \%)$.

If we compare $\delta^{13} \mathrm{C}$ values of white hair from the belly with that of the whiskers and tail, we can see that $\delta^{13} \mathrm{C}$ values of whiskers are generally the most positive, reaching values similar to those of collagen, whereas hair from the tail shows intermediate values between those of the belly and whiskers. 
The differences mentioned above are not observed in any of the types of hair (whiskers, tail, or belly) of the oscollo (Felis sp.), the carnivorous predator of the chozchori rodent, which allows us to conclude that the distribution of $\delta^{13} \mathrm{C}$ values of the animal pelage is homogeneous.

\section{CONCLUSIONS}

Hair is generally considered a short-term animal product, that is, a product of a short-term absorption of nutrients. Therefore, it should be expected that knowing $t h{ }^{13} \mathrm{C} /{ }^{12} \mathrm{C}$ ratio of hair tissue, it would be enough to subtract $1 \%$ from this value to estimate the approximate percentile composition of the original plant diet.

Nevertheless, we find that this statement is not true in all the cases analyzed. For instance, the woolly hair of the guanaco and the vicuña, 2 mammals inhabiting the same environment at the upper heights of the Andes, shows $\delta^{13} \mathrm{C}$ values that are about 5\% more positive than those of diet, which means that $\delta^{13} \mathrm{C}$ values of hair are more similar to those of bone collagen. This difference is worth studying in a larger number of cases due to its potential use in archaeology. Archaeological cloth made with this same type of animal fiber is often found in prehistoric burial sites, and is sometimes used for ${ }^{14} \mathrm{C}$ dating. The measurement of $\delta^{13} \mathrm{C}$ values in archaeological cloth with known ${ }^{14} \mathrm{C}$ ages would allow one to obtain information about the type of pasture $\left(\mathrm{C}_{3}\right.$ or $\left.\mathrm{C}_{4}\right)$ grazed upon by the prehistoric animals, and would thus be valuable as a paleoenvironmental indicator.

The rodents studied (Octodontomys) represent the first active link of the local food chain. Rough seasonal conditions affect the composition of their predominant diet, which changes from cacti in winter to an apparently graded mixture of CAM species with a proportion of up to $30 \%$ of $\mathrm{C}_{3}$ grasses in summer.

The analytical results of the present study show that the passage or fixation in hair tissue of the isotopic values of a typically contrasting diet $\left(\mathrm{C}_{3} / \mathrm{CAM}\right.$ photosynthesizing as $\left.\mathrm{C}_{4}\right)$ is not verified with equal speed and homogeneity in primary consumers. Some types of hair seem to be more metabolically active than others or, at least, hair from different parts of the body of the same individual can have significantly different isotopic values.

Apparently, the factor that determines the distribution of carbon isotopes in hair is the residence time of hair in the living individual. Hair on the rodent's belly, which is directly related to reproductive functions, appears to have the shortest life-span, since it shows faster turnover rates. Nevertheless, sampling of free animals necessarily involves the inclusion of hair from different growth stages, ages or seasons, which results in a mixture of isotopic values. Therefore, it is only relatively true that $\delta^{13} \mathrm{C}$ values of hair can give information about the food eaten during a short period prior to death.

Other types of hair, such as whiskers, whose function is important to rodents throughout their lives, remain on the individual for a longer period of time and, thus, tend to accumulate isotopic values corresponding to older components of the diet. Therefore, whiskers tend to have a slower turnover rate than hair and their $\delta^{13} \mathrm{C}$ values become similar to those measured on bone collagen of the same individual.

The remarkable shift in isotopic composition between diet and hair is only verified in the first link of the food chain, in our case, the large (camelids) and small herbivores (rodents).

In those animals that do not significantly modify their diets throughout the year, such as the puma, who eats camelids, and the wildcat or oscollo and the fox, who eat chozchoris (Octodontomys), $\delta^{13} \mathrm{C}$ 
values are relatively constant no matter the type of hair (with long or short residence time) on which the measurement is done, and these values coincide with those of collagen.

Taking into account the relevance of the facts observed and the dietary and paleodietary interest of the results obtained on a small number of cases, together with the possible paleoenvironmental implications and their potential use in archaeology, it would be interesting to extend this research to a larger number of individuals and their respective microenvironments.

\section{ACKNOWLEDGMENTS}

Authors are indebted to the stable isotopes laboratory of INGEIS for performing the isotopic analyses. This work is dedicated to the memory of Jorge Fernández C, who passed away on 24 December 2001.

\section{REFERENCES}

Craig H. 1957. Isotopic standards for carbon and oxygen and correction factors for mass spectrometric analysis of carbon dioxide. Geochimica et Cosmochimica Acta 12:133-49.

DeNiro MJ, Epstein S. 1978. Influence of diet on the distribution of carbon isotope in animals. Geochimica et Cosmochimica Acta 42:495-506.

Fernández C J, Panarello HO, Schöbinger J. 1999. The Inca mummy from Mount Aconcagua: decoding the geographic origin of the "Messenger to the Deities" by means of stable carbon, nitrogen and sulphur isotope analyses. Geoarchaeology 14(1):24-46.

Jones RJ, Ludlow MM, Troughton JH, Blunt CG. 1979. Estimation of the proportion of $\mathrm{C}_{3}$ and $\mathrm{C}_{4}$ plant species in the diet of animals from the ratio of natural ${ }^{13} \mathrm{C}$ and ${ }^{13} \mathrm{C}$ isotopes in the faeces. Journal of Agricultural Science 92:91-100.

Gonfiantini R. 1984. In: Advisory Group Meeting on Stable Isotope Reference Samples for Geochemical and Hydrological Investigations. Vienna $75 \mathrm{p}$.

Jones RJ, Ludlow MM, Troughton JH, Blunt CD. 1981. Changes in the natural carbon isotope ratios of the hair from steers feed diets of $\mathrm{C}_{4}, \mathrm{C}_{3}$ and $\mathrm{C}_{4}$ species in sequence. Search 12(3-4):85-7.

Katzenberg NM, Krouse HR. 1989. Application of stable isotope variation in human tissues to problems of identification. Canadian Society for Forensic Sciences Journal 22:7-19.

Minson DJ, Ludlow MM, Troughton JH. 1975. Differences in natural carbon isotope ratios of milk and hair from cattle grazing tropical and temperate pastures. Nature 256:602.
Nakamura K, Schoeller DA, Winkler FJ, Schmidt HL. 1982. Geographical variation in the carbon isotope composition of the diet and hair in contemporary man. Biomedical Mass Spectrometry 9:390-4.

Panarello HO. 1987. Relaciones entre concentraciones de isótopos livianos utilizados como indicadores ambientales y de paleotemperaturas. $\mathrm{PhD}$ thesis. Universidad de Buenos Aires. 103 p. In Spanish.

Sealy JC, van der Merwe NJ. 1986. Isotope assessment and the seasonal-mobility hypothesis in the southwestern Cape of South Africa. Current Anthropology 27:135-50

Schwarcz HP, Schoeninger MJ. 1991. Stable isotope analyses in human nutritional ecology. Yearbook of Physical Anthropology 34:283-321.

Schoeller DA, Minigawa M, Slater R, Kaplan IR. 1986. Stable isotopes of carbon nitrogen and hydrogen in the contemporary North America food web. Ecology of Food and Nutrition 18:159-70.

Tieszen LL, Boutton TW, Tesdahl KG, Slade NA. 1983. Fractionation and turnover of stable carbon isotopes in animal tissues, implications for ${ }^{13} \mathrm{C}$ analysis of diet. Oecologia 57:32-7.

van der Merwe MJ. 1982. Carbon isotopes, photosynthesis and archaeology. American Scientist 70:596-606.

van der Merwe MJ. 1986. Carbon isotope ecology of herbivores and carnivores. Palaeoecology of Africa 17: 123-31.

White CD. 1993. Isotopic determination of seasonality in diet and death from Nubian mummy hair. Journal of Archaeological Science 20:657-66. 